\title{
Woody Plant Community in the Cross Timbers Over Two Decades of Brush Treatments
}

\author{
David M. Engle, ${ }^{1}$ Timothy N. Bodine, ${ }^{2}$ and J. F. Stritzke ${ }^{1}$ \\ Authors are ${ }^{1}$ former Regents Professor, Department of Plant and Soil Sciences; ${ }^{2}$ former graduate student, \\ Department of Animal Sciences; and ${ }^{1}$ Professor Emeritus, Department of Plant and Soil Sciences, \\ Oklahoma Agricultural Experiment Station, Stillwater, OK 74078.
}

\begin{abstract}
The closed overstory of fire-adapted forests throughout the world precludes surface fires of sufficient intensity to open the overstory. The cross timbers, an upland oak forest that spans an area from Texas to Missouri, developed with frequent fire, but removal of fire since European settlement has increased canopy cover of dominant overstory trees. To assess response of woody plant species cover and plant community compositional trajectories to brush treatments that included herbicides and fire in the cross timbers, we analyzed a 20-year data set (1982-2001) from untreated pastures, pastures treated with tebuthiuron or triclopyr in 1983, and pastures treated with tebuthiuron or triclopyr in 1983 and burned periodically thereafter (tebuthiuron + fire and triclopyr + fire). We used analysis of variance to determine change in overstory canopy cover and understory canopy cover in response to experimental treatment, and we used detrended correspondence analysis to assess trajectories of species composition over time. Overstory canopy cover was reduced from more than $100 \%$ to less than $20 \%$ following initial herbicide application, but canopy cover increased subsequently to over $60 \%$ as herbicide-resistant woody species increased in all but the tebuthiuron + fire treatment. The most striking change in overstory occurred in the tebuthiuron + fire pastures, which contained almost $20 \%$ cover of sumac (Rhus spp.) by 1994, and in the tebuthiuron pastures, which contained $>40 \%$ cover of eastern redcedar (Juniperus virginiana L.) by 1994. Tebuthiuron, both with and without fire as a follow-up, influenced composition of the overstory more than did triclopyr. Application of tebuthiuron appears to be a long-term unidirectional disturbance in the cross timbers. Composition also remained distinct from pretreatment condition in triclopyr-treated pastures after almost 20 years of postherbicide succession. In contrast, the understory woody plant community was quite resilient to both herbicides.
\end{abstract}

\section{Resumen}

El estrato superior cerrado de los bosques adaptados al fuego que se encuentran a través del mundo previene los incendios superficiales de intensidad suficiente como para abrir este estrato. El "cross timbers," un bosque de encino de altiplanicie que cubre una área de Texas a Missouri, Estados Unidos de América, se desarrolló con incendios frecuentes, pero la supresión de ellos desde la colonización Europea ha incrementado la cobertura de copa de los árboles dominantes del estrato superior. Para evaluar la respuesta de la cobertura de especies leñosas y las trayectorias de la composición botánica de la comunidad a tratamientos de control de arbustos que incluyeron herbicidas y fuego aplicados en el "Cross timbres," analizamos un juego de datos de 20 años (1982 a 2001) de potreros sin tratar, potreros tratados con tebutiuron o triclopir en 1983 y potreros tratados con tebutiuron o triclopir en 1983 y quemados periódicamente después de la aplicación (tebutiuron + fuego y triclopir + fuego). Usamos el análisis de varianza para determinar el cambio en la cobertura de copa de los estratos superior e inferior en respuesta a los tratamientos experimentales y usamos análisis de correspondencia de tendencias para evaluar las trayectorias de la composición de las especies en el tiempo. Después de la aplicación inicial de herbicida, la cobertura de copa del estrato superior se redujo de más del $100 \%$ a menos de $20 \%$, sin embargo, posteriormente aumentó a más del $60 \%$, conforme las especies leñosas resistentes a los herbicidas se incrementaron, esto se observó en todos los tratamientos menos en el de tebutiuron + fuego. El cambio más notorio del estrato superior ocurrió en los potreros tratados con tebutiuron + fuego, en los que en 1994, casi el $20 \%$ de la cobertura era de "Sumac" (Rhus spp.) y en los potreros tratados con tebutiuron, en los cuales en esa fecha más del $40 \%$ de la cobertura era de "Eastern redcedar" (Juniperus virginiana L.). El tebutiuron, con o sin fuego aplicado como herramienta de control posterior, influenció la composición del estrato superior más que el triclopir. La aplicación de tebutiuron parece ser un disturbio unidireccional de largo plazo en los bosques "cross timbers." Después de casi 20 años de sucesión posterior a la aplicación de los herbicidas, en los potreros tratados con triclopir, la composición también permaneció distinta a la presente antes de aplicar el tratamiento. En contraste, la comunidad de plantas leñosas del estrato inferior fue muy resilente a ambos herbicidas.

Key Words: brush control, brush management, Quercus marilandica, Quercus stellata, prescribed fire, tebuthiuron, triclopyr, upland hardwood forest

\section{INTRODUCTION}

Correspondence: David M. Engle, 339 Science II, Dept of Natural Resource Ecology and Management, lowa State University, Ames, IA 50011. Email: dme@iastate.edu

Manuscript received 20 June 2005; manuscript accepted 22 November 2005.
The upland oak-dominated forests of the cross timbers, which encompass substantial land area from Texas to Missouri (Hoagland et al. 1999), developed with frequent fire into a mosaic of closed canopy forest, savannah, and open grassland 
(Irving 1835; Gregg 1844). Reduction of fire since European settlement in the late 1800 s increased canopy cover of dominant overstory oaks (Quercus spp.) in most stands of cross timbers (Bruner 1931; Dyksterhuis 1948; Abrams 1992). At a few locations, frequent fire maintained open stands of oak trees (Wethington 1994; Engle et al. 1996a). Phenoxy herbicides, used since the 1950 s primarily to increase forage grasses, temporarily opened up these oak forests (Elwell et al. 1974). However, fire and herbicide that top-kill oaks induce hardwood resprout thickets that differ considerably from pre-European settlement stand structure, and these brush thickets do not support profitable enterprises (Engle 1997). Long-term economic output of ranches using enterprises with domestic and wild herbivores can be optimized with judiciously applied herbicides and fire applied in combination to maintain woody plant control (Bernardo and Engle 1990; Bernardo et al. 1992).

In the initial phase of a long-term study in the cross timbers of north-central Oklahoma, treatment with tebuthiuron $(\mathrm{N}-[5-$ (1,1-dimethylethyl)1,3,4-thiadiazol-2-yl]-N,N'-dimethylurea), or triclopyr ([(3,5,6-trichloro-2-pyridinyl)oxy]acetic acid), both with and without burning, reduced woody plant cover and altered woody species composition (Stritzke et al. 1991) and increased grasses (Engle et al. 1991). However, consequences of these treatments and follow-up maintenance treatments on the woody plant community over a longer time period have not been reported even though brush herbicide use within the cross timbers is common (Boren et al. 1997b), even in cross timbers restorations (Engle et al. 1996a).

Therefore, we examined a 20-year (1982-2001) data set from the study described initially by Stritzke et al. (1991) in which herbicides and fire together with other follow-up treatments were applied to manipulate woody plant species cover and composition. Because, as shown by Stritzke et al., triclopyr and tebuthiuron differed little in early effects on woody vegetation, we expected both herbicides to reduce canopy cover similarly and similarly alter woody plant species composition over the long term. Based on results from Stritzke et al., we expected follow-up treatments to either tebuthiuron or triclopyr to maintain reduced woody plant canopy cover and altered species composition. The objective of this study was to determine the long-term influence of brush treatments on woody plant species cover and community compositional trajectories in the cross timbers of Oklahoma.

\section{MATERIALS AND METHODS}

\section{Study Location, Climate, Soils, and Vegetation}

The study was initiated in 1982 on the Cross Timbers Experimental Range located $11 \mathrm{~km}$ southwest of Stillwater, Oklahoma (lat $36^{\circ} 03^{\prime} \mathrm{N}$, long $97^{\circ} 12^{\prime} \mathrm{W}$, elev. $331 \mathrm{~m}$ ) (Stritzke et al. 1991). Climate at the location is continental with an average frost-free growing period of 204 days. Annual precipitation averages $831 \mathrm{~mm}$ with $65 \%$ falling as rain from May to October. The mean annual temperature is $15^{\circ} \mathrm{C}$ and ranges from an average daily minimum of $-4.3^{\circ} \mathrm{C}$ in January to an average maximum of $34^{\circ} \mathrm{C}$ in August (Myers 1982; NOAA 1999).

Woody species associated with the cross timbers of the study area occur on 2 upland ecological sites, shallow savannah
(Stephenville-Darnell complex; shallow soils) and sandy savannah (Harrah-Pulaski complex; deep soils) (Ewing et al. 1984). Stephenville soils are fine-loamy, siliceous, thermic Ultic Haplustalfs, and Darnell soils are loamy, siliceous, thermic, shallow Udic Ustochrepts. Harrah soils are fine-loamy, siliceous, thermic Ultic Paleustalfs, whereas Pulaski soils are coarse-loamy, mixed, nonacid, thermic Typic Ustifluvents. Sandy savannah sites are alluvial and typically occur on the lower slopes and ridge shoulders with deeper soils along the stream channels. Upper slopes and ridges are predominately shallow savannah sites with a sandstone base (Henley et al. 1987). Interspersed with the upland forest sites was successional vegetation structurally similar to tallgrass prairie found largely on previously cleared and cultivated sites abandoned in 1936 (Ewing et al. 1984).

When the study was initiated in 1982, oaks dominated the diverse woody species composition of near relict forest (Ewing et al. 1984). Overstory canopy cover was dominated by post oak (Quercus stellata Wangenh.) and blackjack oak (Quercus marilandica Muenchh.). Chinquapin oak (Quercus muehlenbergii Engelm.), rough-leaf dogwood (Cornus drummondii Meyer), eastern redcedar (Juniperus virginiana L.), redbud (Cercis canadensis L.), American elm (Ulmus Americana L.), hackberry (Celtis spp.), and gum bumelia (Bumelia lanuginose [Michx.] Pers.) were important components of the overstory. Dominant woody plant species in the understory included the same overstory species together with winged sumac (Rhus copallina L.), greenbrier (Smilax bona-nox L.), grape (Vitis spp.), blackberry (Rubus spp.), Mexican plum (Prunus mexicana Wats.), and buckbrush (Symphoricarpus orbiculatus Moench.). The dominant herbaceous species were little bluestem (Schizachyrium scoparium [Michx.] Nash), indiangrass (Sorghastrum nutans [L.] Nash), big bluestem (Andropogon geradii Vitman), Scribner's panicum (Panicum oligosanthes Schult.), purpletop (Tridens flavus [L.] Hitchc.), lespedeza (Lespedeza spp.), and western ragweed (Ambrosia psilostachya D.C.) (Ewing et al. 1984).

\section{Experimental Design, Treatments, and Follow-up Management}

Five treatments were replicated 4 times on 20 pastures (about 32.4 ha each) with the 4 replications blocked according to area of soil type and area of cross timbers vegetation type within a pasture. The study was designed initially as a randomized complete block design with a $2 \times 2$ (herbicide $\times$ fire) factorial arrangement of treatments plus a control with no herbicide and no fire (Table 1). The factorial arrangement of treatments was discontinued in 1993. Initial herbicide treatments in 1983 were applications of tebuthiuron or triclopyr applied aerially and uniformly across the entire pasture. Fire treatments were the application of either no fire or a dormant-season (January to early April) prescribed broadcast fire annually from 1985 to 1987 and then every 3 years from 1990 to 1999 as a follow-up treatment to the herbicide applications.

Tebuthiuron, a soil-applied pelleted herbicide, was applied at $2.2 \mathrm{~kg}$ active ingredient $\mathrm{ha}^{-1}$ in March 1983, and a low volatile ester formulation of triclopyr, a foliar-applied herbicide, was applied at $2.2 \mathrm{~kg}$ acid equivalent $\mathrm{ha}^{-1}$ in June 1983. Rainfall after application of tebuthiuron $(57,41$, and $189 \mathrm{~mm}$ of precipitation for March, April, and May, respectively) was 
Table 1. Brush treatments imposed on study pastures of the Cross Timbers Experimental Range from 1983 to 2001.

\begin{tabular}{|c|c|c|c|c|}
\hline Treatment & $\begin{array}{l}\text { Herbicide } \\
\text { (year) }\end{array}$ & $\begin{array}{l}\text { Year of } \\
\text { broadcast burning }\end{array}$ & $\begin{array}{l}\text { Year of } \\
\text { individual tree } \\
\text { burning }\end{array}$ & $\begin{array}{l}\text { Description of mechanical } \\
\text { control of Eastern } \\
\text { redcedar (year) }\end{array}$ \\
\hline Tebuthiuron & Tebuthiruon (1983) & None & None & None \\
\hline Tebuthiuron + fire & $\begin{array}{l}\text { Tebuthiuron (1983), } \\
\text { picloram and 2,4-D (1997) }\end{array}$ & $\begin{array}{c}1985,1986,1987,1990 \\
1993,1996,1999\end{array}$ & 1990, 1993, 1996 & None \\
\hline Triclopyr & $\begin{array}{c}\text { Triclopyr (1983), 2,4-D (1988), } \\
\text { picloram and 2,4-D (1994) }\end{array}$ & 1993, 1996, 1999 & 1996 & $\begin{array}{l}\text { Dozer crushing before } \\
\text { broadcast burn (1996) } \\
\text { Rotary saw after } \\
\text { broadcast burn (1996) }\end{array}$ \\
\hline Triclopyr + fire & Triclopyr (1983), 2,4-D (1988) & $\begin{array}{c}\text { 1985, 1986, 1987, } 1990 \\
\text { 1993, 1996, } 1999\end{array}$ & 1990, 1993, 1996 & None \\
\hline Control & None & None & None & None \\
\hline
\end{tabular}

sufficient to move tebuthiuron into the soil. Environmental conditions and tree growth in June were satisfactory for good foliar uptake and activity of triclopyr (Stritzke et al. 1991).

Prescribed broadcast fires were conducted using stripheadfires beginning in 1985 when fine fuel load limited burning primarily to grassland sites (Table 1). By 1986, some cross timbers sites burned (primarily the shallow savannah sites), and by 1987 , about $25 \%$ of cross timbers in triclopyr-treated pastures and $>50 \%$ of the cross timbers sites in tebuthiurontreated pastures burned.

Pastures treated with triclopyr were treated with an aerial application of 2,4-D, [(2,4-dichlorophenoxy)acetic acid] applied at $1.1 \mathrm{~kg}$ acid equivalent ha ${ }^{-1}$ in June 1988 to suppress understory brush (Table 1). To allow accumulation of fine fuel for burning in 1993, cattle were not stocked on triclopyrtreated pastures in 1992. Previously unburned triclopyr pastures were included in the burning treatment beginning in 1993. In 1997, burned, tebuthiuron-treated pastures were treated with the commercially available premix of picloram (4-amino3,5,6-trichloropicolinic acid) and 2,4-D at 0.55 and $0.14 \mathrm{~kg}$ acid equivalent $\mathrm{ha}^{-1}$, respectively, to control fire-tolerant resprouting shrubs, primarily winged sumac and rough-leaf dogwood, which were gaining canopy dominance and decreasing production of forage and fine fuel. Control of eastern redcedar in the triclopyr-only treatment was initiated in 1996 with a dozer-mounted push blade followed by prescribed burning and then by removal by a tractor-mounted hydraulic rotary saw. To further reduce eastern redcedar, prescribed burning as ignitions of individual trees (Engle and Stritzke 1992) was used in 1990-1996 as a follow-up treatment to prescribed broadcast burning of entire pastures.

\section{Grazing Management}

Cattle did not graze experimental pastures in 1982, whereas yearling cattle and mature cows grazed from July 1983 through February 1984. From 1985 through 1994, yearling cattle grazed pastures during the growing season with season-long stocking (SLS) from early April through late September. Beginning in 1995, yearling cattle grazed 2 pastures in each block of each treatment under SLS (April to September) and the remaining 2 pastures with intensive early stocking (IES, double the stocking density for the first half of the grazing season, April to July). We annually set stocking rate by pasture according to expected change in forage production in response to brush treatment and by adjusting to the previous year's end-of-season residue of herbaceous standing crop. We used a pasture mean of $1500 \mathrm{~kg} \mathrm{ha}^{-1}$ of residual herbaceous standing crop as a target in all pastures except for the control pastures where we used the residue only in prairie openings as a basis on which to adjust stocking rate. Control pastures contained insufficient forage within stands of trees to support grazing use (Engle et al. 1991).

\section{Vegetation Sampling}

We used 6 permanent, 30-m line transects established by Ewing et al. (1984) in each pasture (120 total transects per year). The line intercept method (Canfield 1941) was used to estimate canopy cover during the growing season for overstory $(>1 \mathrm{~m}$ height) and understory ( $<1 \mathrm{~m}$ height) woody plant species to separate the responses of sprouting trees, shrubs, vines, or juvenile trees in the understory from that of overstory trees. Observations were made every 2 years from 1982 until 1988 and subsequently about every 3 years (1991, 1994, 1998, and 2001) for a total of 8 samples. Our analyses did not include samples from one pasture on the tebuthiuron-only treatment in 1998 and 2001 because a wildfire burned across the pasture in 1996 .

\section{Data and Statistical Analyses}

The response variable was percentage canopy cover by species transformed from meters of line intercept for 20 woody plant species occupying either overstory or understory. Canopy cover was averaged across transects within range site, pasture, and year resulting in 316 total observations (2 range sites, 20 pastures, and 8 years minus the 2 observations for 1998 and 2001 for the pasture burned by the 1996 wildfire). When canopy cover of either a single species or a species group including total overstory and total understory cover was $\leq 100 \%$, data were transformed using the angular transformation (Quinn and Keough 2002). We used analysis of variance (PROC MIXED, SAS Institute, Inc, Cary, NC) with repeated measures to assess treatment differences in canopy cover of woody plant species and selected species groups. Replicate, treatment, time, and the interaction between 

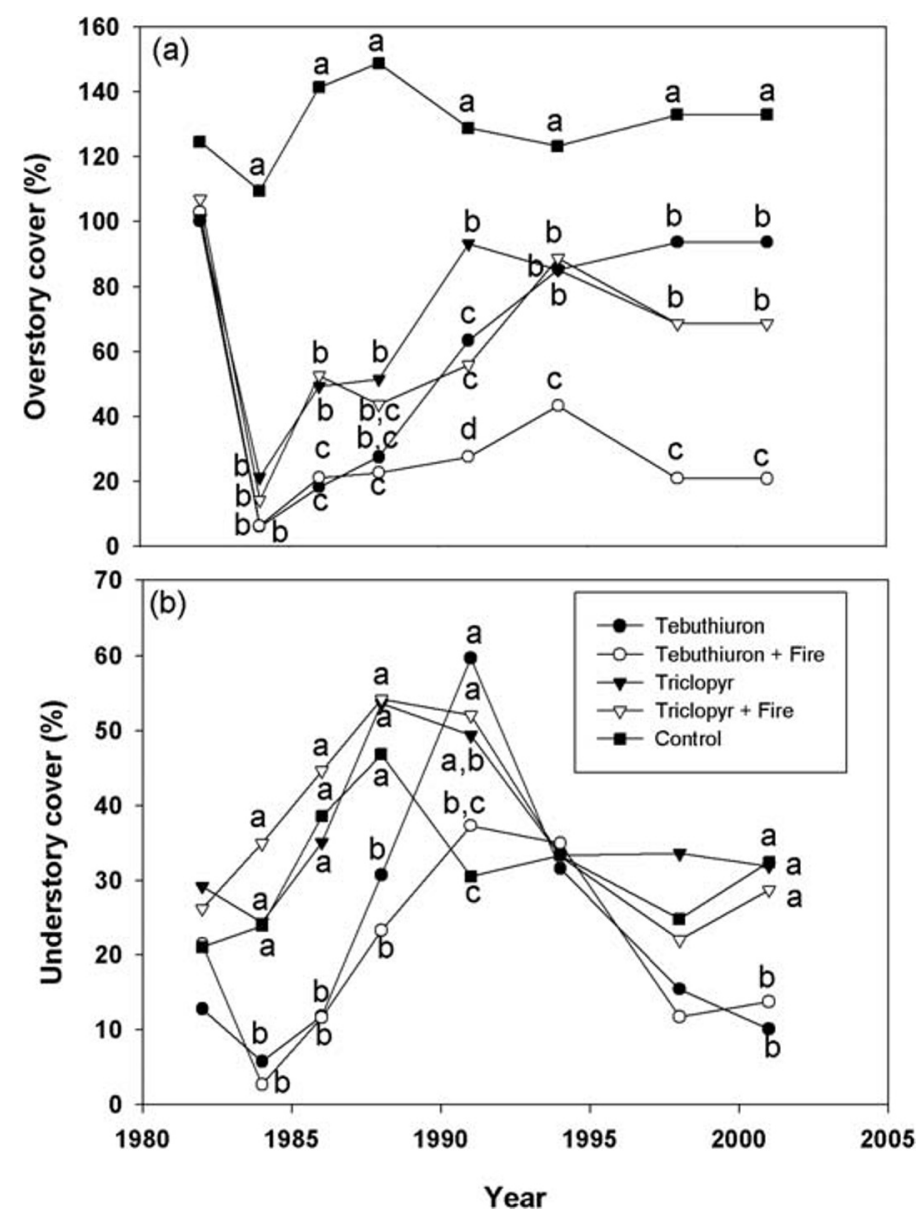

Figure 1. Canopy cover of the (a) overstory woody plant community and (b) understory woody plant community at the Cross Timbers Experimental Range in central Oklahoma within brush treatments. Treatment means within a year without common letters differ $(P<0.05)$.

treatment and time were treated as fixed effects using Satterthwaite degrees of freedom approximation techniques. We considered transects within pastures as the subject of the repeated measures and adopted a first-order autoregressive $(\mathrm{AR}(1))$ correlation structure between repeated measures. Treatment means were separated by pairwise comparisons within year in the presence of a significant effect slice for that year (SLICE option) (Littell et al. 1996). Statistical significance in all analyses was accepted at $P \leq 0.05$.

Our primary objective was to determine the influence of brush treatments on community species composition. However, to determine if community species composition differed between sites (shallow savannah and sandy savannah), we used partial canonical correspondence analysis (pCCA; ter Braak 1986, 1988; Hallgren et al. 1999). When compositional variation within a community results from numerous environmental variables, pCCA is particularly useful (Palmer 1993; Hallgren et al. 1999). We coded the categorical explanatory variable, i.e., soil type, as an indicator ( 0 or 1$)$ variable and analyzed the data as a replicated BACI (Before, After, Control, Impact) design with a factorial treatment arrangement using the data for 1982 and 2001 (ter Braak and Šmilauer 1998). Years since the initiation of the study (time) was included as a continuous variable to allow interaction between categorical variables and time as explanatory variables, and time was used as a covariable to measure changes in species composition in response to site and grazing management. We included time by site as explanatory variables, and time, pasture, interaction of grazing system with time, and interaction of time with each experimental treatment combination as covariables. Species data were log transformed, and default options in CANOCO for Windows were accepted as follows: rare species were not down-weighted, scaling was based on interspecies distances, and forward selection of environmental variables was not used. Monte Carlo permutation tests of significance $(n=499)$ were constrained for all ordination axes for a split-plot design, and Monte Carlo permutation tests of significance for all canonical axes were used to interpret change in the plant community in response to site and grazing management (ter Braak and Šmilauer 1998). Species composition did not differ $(P>0.47)$ between sites, so we evaluated community response to treatments across sites in additional analyses.

We used a similar approach to determine if community species composition differed between grazing systems (intensive early stocking vs. season-long stocking). We included time by grazing system as the explanatory variable, and time, pasture, and the interactions of time with each experimental treatment combination as covariables. In the analyses of the treatment combinations over time, we performed pCCA with the interactions between time and experimental treatment combinations as explanatory variables, and time and pasture as covariables. Neither overstory woody vegetation composition nor understory woody vegetation composition differed $(P>0.22)$ between the 2 grazing systems after 7 years (1995-2001). Therefore, we pooled data across sites and grazing management for further analyses.

We used detrended correspondence analysis (DCA; Hill and Gauch 1980; ter Braak and Šmilauer 1998) to express temporal trajectories in species composition within treatments. We performed DCA with square-root transformation on the pooled (i.e., averaged over site and grazing system) data for both overstory and understory data from all years (1982-2001). Species data were log transformed, and default options in CANOCO for Windows were accepted as follows: rare species were not down-weighted, and detrending method was by segments. We plotted mean $(n=4)$ axis 1 and axis 2 site scores for each treatment and year to present visually trajectories of change in species composition over time as a function of experimental treatments.

\section{RESULTS}

\section{Overstory and Understory Canopy Cover}

Overstory and understory canopy cover responded differently to treatments, with greater overall responsiveness to treatments reflected in the overstory than in the understory woody plant community. Overstory canopy cover did not differ among treatments in 1982 (Fig. 1a), but from 1984 to 2001, treated pastures contained less overstory canopy cover than did control pastures. Overstory canopy cover in tebuthiuron treatments was less in 1986 than in triclopyr treatments, and overstory canopy cover was maintained at lower levels in the tebuthiuron + fire treatment pastures than all other treatments from 1991 
to 2001. In contrast, overstory canopy cover in the unburned tebuthiuron treatment did not differ from that of either triclopyr treatment by 1988, and overstory canopy cover in triclopyr-treated pastures was intermediate between the control and tebuthiuron + fire treatments from 1986 to 2001.

From 1984 through 1988, understory canopy cover did not differ between tebuthiuron treatments, and understory cover in both tebuthiuron treatments was less than that of the control and triclopyr-treated pastures, and understory cover in triclopyrtreated pastures did not differ from control pastures. Understory canopy cover did not differ among treatments in 1982, 1994, and 1998 (Fig. 1b). Understory canopy cover was less in both tebuthiuron treatments than other treatments by 2001 .

\section{Species Composition and Vegetation Trajectories}

Overstory Species Composition. Both tebuthiuron and triclopyr changed species composition of the overstory, but tebuthiuron produced the greatest change in composition over the study period. Overstory composition in the control treatment (Fig. 2a) was minimally directional from 1982 to 2001, but species composition of the overstory changed markedly in the 4 brush treatments (Fig. 2 b and 2c) over the course of the study with the greatest change within the tebuthiuron treatments from 1982 to 1984 . Overstory community composition in the tebuthiuron + fire treatment expressed the largest change along DCA axis 1 and axis 2 from 1984 to 1994, but after application of picloram plus 2,4-D in 1997, composition in 1998 and 2001 in the tebuthiuron + fire treatment moved in a trajectory toward composition similar to 1984. Change in overstory composition within triclopyr treatment pastures was also greatest from 1982 to 1984 (Fig. 2c), reflecting the initial application of triclopyr in 1983, but the change along either axis was not as great as that of the tebuthiuron treatments. Burning combined with picloram plus 2,4-D as follow-up to tebuthiuron resulted in greater variation among years along both ordination axes than was exhibited by the triclopyr treatment, despite follow-up herbicides, mechanical treatments, and fire applied to triclopyr treatment beginning in 1988.

All treatments contained at least one woody plant species that increased in the overstory at some point in the study period. Overstory canopy of pastures in the control treatment contained greater cover of oaks, the overstory dominant species of cross timbers, throughout the study period (Fig. 3a). However, the most striking change in overstory occurred in the tebuthiuron + fire pastures, which contained almost $20 \%$ cover of sumac (Fig. 3b) by 1994, and in the tebuthiuron pastures, which contained $>40 \%$ cover of eastern redcedar by 1994 (Fig. $3 c)$. Follow-up application of picloram plus 2,4-D to tebuthiuron + fire treatment pastures in 1997 reduced sumac from the overstory within these pastures. Burning within triclopyrtreated pastures did not result in increases in sumac as was the case with tebuthiuron + fire. Burning more effectively maintained lower canopy cover of eastern redcedar when combined with tebuthiuron than when combined with triclopyr.

Understory Species Composition. Both tebuthiuron and triclopyr also changed species composition of the understory over the study period, but change was considerably less than that of
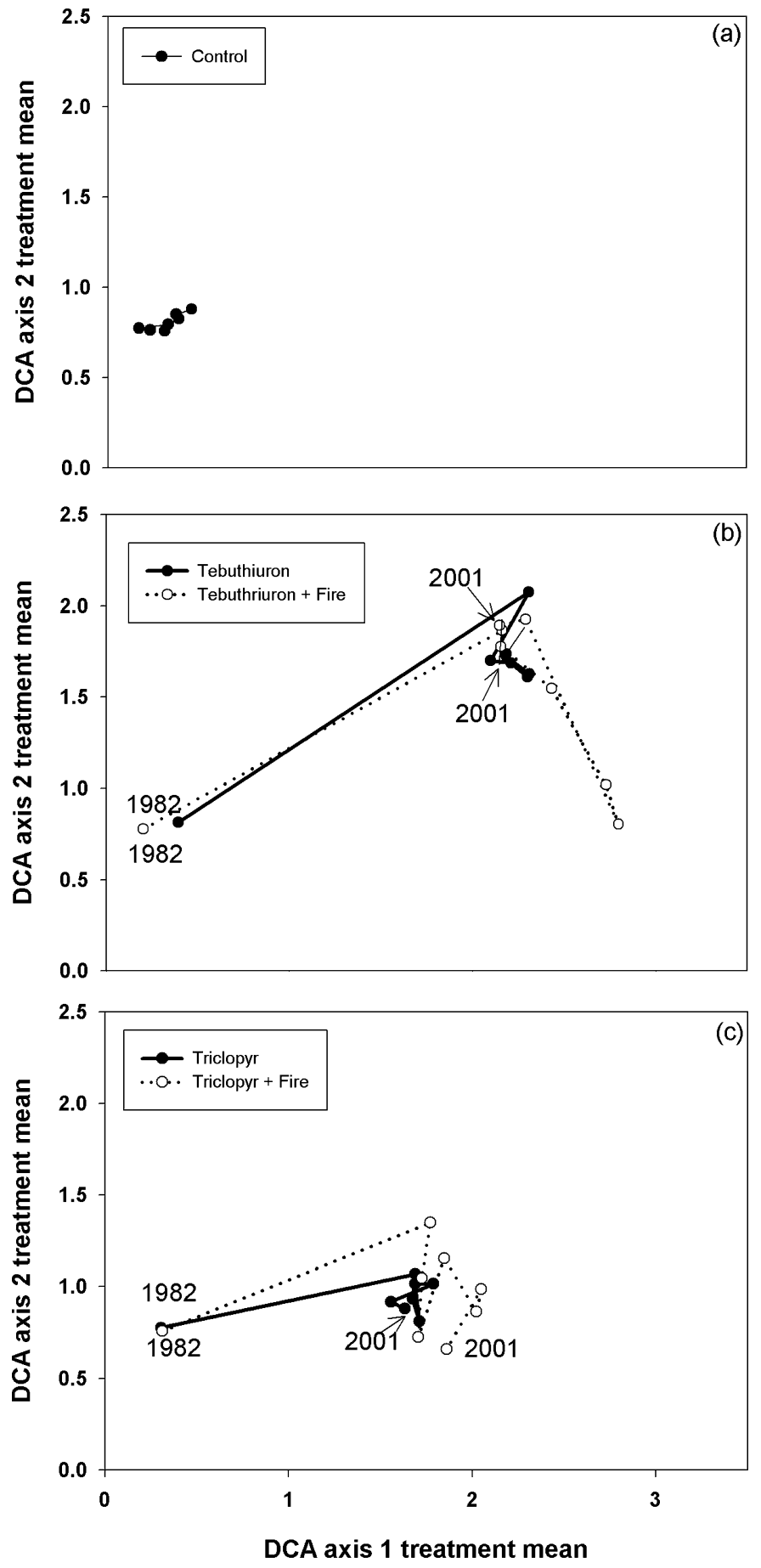

Figure 2. Plot of results of detrended correspondence analysis of overstory woody plant community depicting compositional dynamics from 1982 to 2001 within (a) control, (b) tebuthiuron, and (c) triclopyr brush treatments at the Cross Timbers Experimental Range in central Oklahoma. Points on the plot represent mean site scores $(n=4)$ for a respective date and treatment. Temporally consecutive site scores within a treatment are connected with lines, and pretreatment (1982) mean site scores and end-of-study (2001) mean site scores are identified to indicate community trajectory within treatments. Eigenvalues for axes 1 and 2 were 0.287 and 0.109 , respectively. 

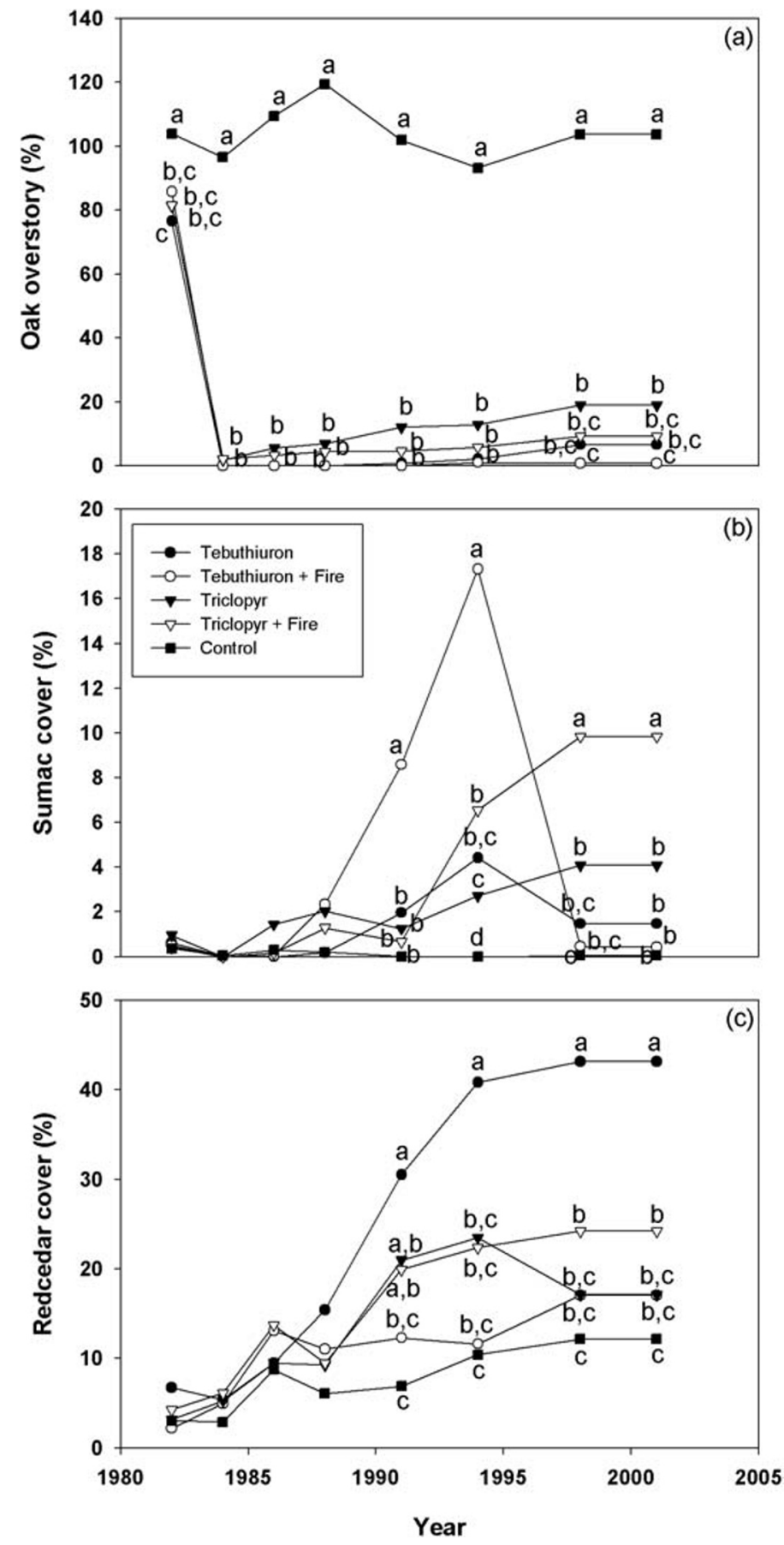

Figure 3. Overstory canopy cover of (a) oak (Quercus spp.), (b) sumac (Rhus spp.), and (c) eastern redcedar (Juniperus virginiana L.) at the Cross Timbers Experimental Range in central Oklahoma within brush treatments. Treatment means within a year without common letters differ $(P<0.05)$.

the overstory (Fig. 4). Composition in the control treatment did not have an interpretable temporal pattern of change from 1982 to 2001 (Fig. 4a), but understory composition within both tebuthiuron treatments diverged from the control from 1982 to 1984 in response to herbicide application in 1983 (Fig. 4b). As was the case in the overstory, understory composition in the tebuthiuron + fire treatment shifted more than in the other 3 treatments. Understory composition in 2001 within
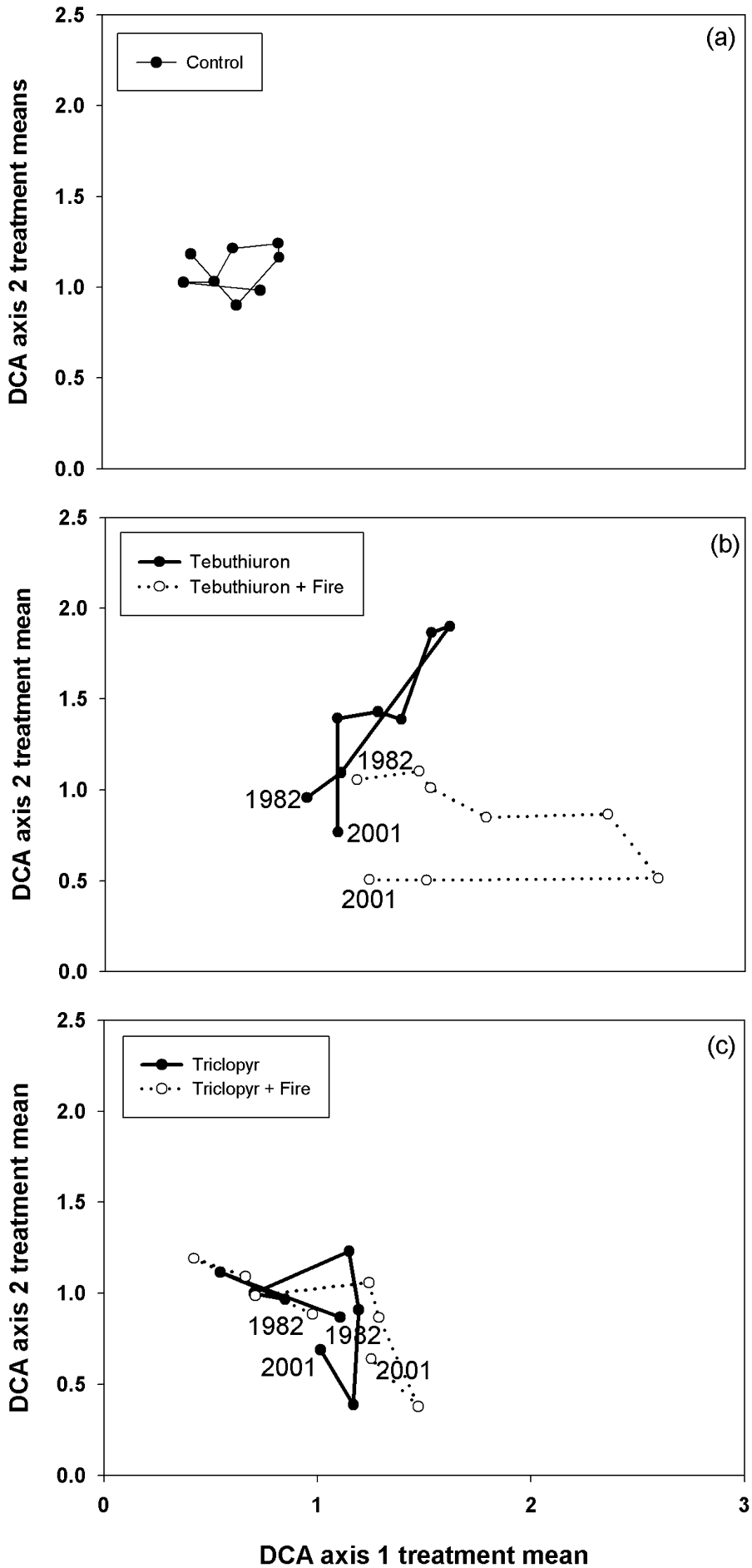

Figure 4. Plot of detrended correspondence analysis of understory woody plant community depicting compositional dynamics from 1982 to 2001 within (a) control, (b) tebuthiuron, and (c) triclopyr brush treatments at the Cross Timbers Experimental Range in central Oklahoma. Points on the plot represent mean site scores $(n=4)$ for a respective date and treatment. Temporally consecutive site scores within a treatment are connected with lines, and pretreatment (1982) mean site scores and end-of-study (2001) mean site scores are identified to indicate community trajectory within treatments. Eigenvalues for axes 1 and 2 were 0.167 and 0.089 , respectively. 
all 4 herbicide treatments was in the direction of pretreatment composition. Compositional change within both triclopyr treatments (Fig. 4c) was small compared to change in tebuthiuron + fire treatment. Temporal pattern of change in community composition was more similar in the 2 triclopyr treatments than in the 2 tebuthiuron treatments, suggesting that fire played a more important role in the tebuthiuron treatment than in the triclopyr treatment.

\section{DISCUSSION}

\section{Community-Level Canopy Cover}

Following a single canopy-removing event, a forested site will succeed to a closed forest if left undisturbed for sufficient time (Oliver 1981; Abrams 1992), but continued disturbance applied to upland hardwood forest in our study precluded restoration of overstory canopy cover even after 20 years of succession following the initial application of herbicide. In fact, tebuthiuron followed by fire maintained overstory canopy cover at less than one-fifth that of the control treatment. Similar results were found over shorter treatment spans following initial treatment with any one of several different herbicides (Stritzke et al. 1975, 1992), but longer-term maintenance of reduced hardwood overstory has not been demonstrated previously in the cross timbers. Although overstory canopy cover in all 4 brush treatments remained at levels below that of the control treatment for the study duration, overstory canopy cover of 3 brush treatments was greater than those of the the tebuthiuron + fire treatment just 8 years after initial herbicide treatment. Moreover, overstory canopy cover in the tebuthiuron without fire treatment responded in a manner similar to the triclopyr treatments in the last half of the study period. This emphasizes the complementary effects of treatment combinations that broaden the spectrum of species suppressed (i.e., integrated brush management systems; see Scifres et al. 1985) even with an herbicide like tebuthiuron that is particularly effective at initial brush treatment.

Brush treatments designed for central North American hardwood forests (e.g., Scifres et al. 1981), including cross timbers (e.g., Elwell et al. 1974), have focused exclusively on reducing the woody overstory and largely ignored woody species in the understory. Understory canopy cover displayed a more complex response to treatments than did overstory canopy cover and varied considerably over the study period within all treatments. Much of this likely can be explained by the complex timing of treatments applied over the course of the study period and the differential response of overstory and understory woody species to fire, herbicide treatment, and mechanical disturbance. Because the woody understory is important to both native and exotic ungulates (Bernardo et al. 1992), it is meaningful to note that at least one time during the study, understory cover in each treatment did not differ from the control. However, through much of the study period, understory canopy cover in the tebuthiuron treatments was considerably lower than all other treatments, suggesting that tebuthiuron is an inappropriate treatment for ungulates for which understory brush is a benefit. Indeed, triclopyr treatments provide superior white-tailed deer habitat over tebuthiuron treatments (Leslie et al. 1996), and triclopyr treatments also can enhance economic returns to ranches that include goat and white-tailed deer enterprises (Bernardo et al. 1992). In contrast, by reducing competition from woody plants and increasing grass production, tebuthiuron together with burning produces superior economic returns in beef cattle enterprises (Bernardo and Engle 1990).

\section{Species Composition and Vegetation Trajectories}

Species composition of the overstory changed over time within all treatments, including the control treatment, which changed mostly because eastern redcedar increased from about 3\% canopy cover to about $12 \%$ canopy cover in the overstory. Eastern redcedar has long been noted for its threat to treeless native grasslands (e.g., Engle et al. 1996b), and our results suggest that, in the absence of fire, cross timbers, a shortstatured upland hardwood forest, is also susceptible to conversion by this shade-tolerant juniper.

Composition of the overstory in any treatment did not recover to pretreatment status or resemble composition of the control treatment even in the treatment that included only a 1983 application of tebuthiuron. In fact, the trajectory of species composition of the overstory in each of the brush treatments was not directional toward that of the control even after 20 years. In contrast, the trajectory of species composition of the understory, unlike the overstory, was directional toward the control even in the tebuthiuron-treated pastures, and this was true even though the early post-treatment trajectories changed species composition more than that of the triclopyr treatments. Tebuthiuron, a soil-applied and root-absorbed herbicide, kills more understory woody plants in the short term (i.e., 5 or 6 years) than triclopyr, a foliar-applied and foliar-absorbed herbicide (Stritzke et al. 1991) because interception of the foliar-applied herbicide by the overstory limits contact with the understory woody plants. Because no observations for longer periods than 6 years have been reported previously with tebuthiuron, our observations are the first to indicate that the more species-rich understory woody plant community is comparatively more resilient than is the overstory community to this widely used herbicide.

Therefore, these results carry significant implications for conservation and restoration programs in the cross timbers. First, overstory cover of oaks, the dominant woody plants in this upland forest, was reduced by the initial herbicide treatments and remained low for the duration of the study. Perhaps a more profound implication is the striking temporal trajectory of species composition of the overstory in the tebuthiuron treatment, which diverged over time from the control. Short-term (3 to 6 years) kill of oaks and conversion of upland oak forest with tebuthiuron has been demonstrated (Scifres et al. 1981; Strizke et al. 1991), but our study indicates the type-conversion (i.e., species replacement) with tebuthiuron is more substantial than with triclopyr and is not reversed within 2 decades. Species composition of the overstory within triclopyr-treated pastures reflects the greater tolerance compared to tebuthiuron of the target species to an application of a broadleaf, foliar herbicide (Elwell et al. 1974; Stritzke et al. 1975; Stritzke et al. 1991), and the tolerance of overstory oaks to low-intensity fire (Hengst and Dawson 1994). As in other oak systems in which tebuthiuron has been used for releasing understory grasses for grazing livestock (Pettit 1979; Scifres et al. 1981; Smith et al. 
1987), tebuthiuron creates species composition in cross timbers that differs greatly from the composition that preceded European settlement (Hoagland et al. 1999). In the sense that recruitment of some species present before treatment with tebuthiuron can be limited by ability of those species to disperse to new sites, sites treated with tebuthiuron might resemble hardwood forests of eastern North America and Europe that can take centuries to recover from long-term cultivation (Flinn and Vellend 2005). Hence, broadcast application of tebuthiuron represents an untenable management option for restoring cross timbers.

In both tebuthiuron- and triclopyr-treated pastures, compositional trajectories of the overstory never moved toward pretreatment condition. That the community did not recover within 2 decades is probably unlike the lower-amplitude compositional shift created by the phenoxy herbicides applied widely in previous decades (e.g., Elwell et al. 1970). Hence, in the cross timbers, broadcast application of brush herbicide and tebuthiuron, especially, carries significant economic and conservation risk. First, post-tebuthiuron vegetation presents a narrower suite of potential enterprise than does cross timbers managed with other tools (Bernardo et al. 1992; Weir and Engle 1999). Second, broadcast application of herbicides is potentially harmful to regional biodiversity given the conservation value of the cross timbers with its relatively small area and its distinctive character (Therrell and Stahle 1998) coupled with conversion to monoculture pasturelands and exurban development (Boren et al. 1997a; Engle et al. 1999).

Removing the dominant overstory plants with these herbicides releases treatment-resistant species advantageously filling canopy gaps, a phenomenon common to other disturbances within North American forests (Oliver 1981). With frequent fire added as a follow-up treatment, many herbicide-resistant species are controlled (Elwell et al. 1970; Stritzke et al. 1975), but the effects are offset by increases in fire-tolerant species such as poison ivy or fire-enabled resprouting species such as sumac (Lay 1956; Anderson et al. 1970; Briggs et al. 2005). The challenge to brush management in the cross timbers is that after the original broadcast application of herbicide, the vegetation requires repeated, multiple follow-up treatments to prevent dominance by a single or few woody species with limited resource value. For example, eastern redcedar will dominate stands treated with either triclopyr or tebuthiuron and requires aggressive control efforts to maintain it at levels compatible with enterprises relying on livestock and wildlife.

Fire played a powerful role in shaping the structure of cross timbers vegetation before European settlement (Engle et al. 1996a; Hoagland et al. 1999). Especially in pastures treated with tebuthiuron, fire is a powerful force that alters species composition in the overstory and understory of cross timbers vegetation. Sumac (Rhus spp.), noted for release with the removal of the dominant oak overstory (Petranka and McPherson 1979) and a shrub that increases with fire (Rasmussen and Wright 1988; Hoagland et al. 1999), dominated the overstory in the tebuthiuron + fire pastures by 1994 after these pastures had been burned 5 times. In contrast, eastern redcedar, a fireintolerant species, dominated the overstory in the tebuthiurononly pastures.

The understory woody plant community is sensitive to fire because fire intensity is sufficient to topkill most of the understory woody plants (Adams et al. 1982; Stritzke et al. 1991; Engle and Stritzke 1995; Sparks et al. 1999). In our study, fire exerted a large influence as a follow-up treatment to tebuthiuron but had little influence on community composition in the triclopyr treatments. The similarity between the 2 triclopyr treatments can be attributed to greater woody plant growth and less growth of warm-season grasses necessary to support dormant-season fires (Engle et al. 1991; Stritzke et al. 1991). Even after repeated follow-up applications of broadleafselective, foliar-applied herbicide (2,4-D in 1988, picloram plus $2,4-\mathrm{D}$ in 1994 ) to control woody plants in the triclopyr-treated pastures, community composition of the understory differed little between the 2 triclopyr treatments.

\section{MANAGEMENT IMPLICATIONS}

The cross timbers, still the most unfragmented forest in eastern North America (Therrell and Stahle 1998), will likely experience increasing fragmentation from both urban and exurban development of 4 nearby rapidly expanding metropolitan areas (Dallas-Fort Worth, Oklahoma City, Tulsa, and Kansas City). As in other rangelands in the region (Kreuter et al. 2004), traditional land use of the cross timbers for cattle grazing is rapidly giving way to contrasting alternative land uses of new ownership groups. Whereas one group of owners (e.g., recreational hunters) values land for purposes consistent with native vegetation, another ownership group (e.g., cattle producers) values land that often dictates complete cover-type conversion. The latter group sometimes clears brush and establishes introduced forage grasses, especially bermudagrass (Cynodon dactylon [L.] Pers.), often to support horse enterprises, in the form of both recreational ranchettes and commercial ranches (Boren et al. 1997a). Because of the aesthetics of trees in an otherwise sparsely treed region, cross timbers landscapes also are prime development areas supporting high-end housing developments.

Our analysis of this long-term data set validates the longterm planning perspective that landowners should employ when contemplating a brush herbicide on previously untreated stands of cross timbers. Clearly, consequences of brush treatment decisions are long term. Brush management research in the cross timbers has heretofore been couched largely in the context of long-term economics of brush treatments through net income maximization from more-or-less traditional agricultural enterprises (Bernardo and Engle 1990; Bernardo et al. 1992). Our study suggests that choosing not to use a brush herbicide retains the greatest range of future land-use alternatives, and potentially the greatest land value, even if not the greatest net income from traditional livestock enterprises. Conversely, choosing to apply a brush herbicide, especially tebuthiuron, provides fewer future land-use alternatives because mature hardwoods, valued for both development and recreation (Weir and Engle 1999), do not reappear in the decades following herbicide application either with or without follow-up maintenance treatments. Restoring cross timbers to pre-European settlement composition is likely impossible within a reasonable planning horizon after a single broadcast application of a brush herbicide. 


\section{ACKNOWLEDGMENTS}

The authors wish to thank station superintendent John Weir for his assistance, the many graduate students and research technicians for assistance in the collection of the data, and Dr Mike Palmer, Department of Botany, for assistance with ordination and comments on an early draft of the manuscript and Dr Mark Payton, Department of Statistics, Oklahoma State University, for assistance with the statistical analyses. Published with the approval of the Director, Oklahoma Agricultural Experiment Station, through project S-1822.

\section{LITERATURE CITED}

Aвrams, M. D. 1992. Fire and the development of oak forests. BioScience 42: 346-353.

Adams, D. E., R. C. Anderson, and S. L. Collins. 1982. Differential response of woody and herbaceous species to summer and winter burning in an Oklahoma grassland. Southwestern Naturalist 27:55-61.

Anderson, K. L., E. F. Smith, and C. E. Owensby. 1970. Burning bluestem range. Journal of Range Management 23:81-92.

Bernardo, D. J., and D. M. Engle. 1990. The effect of manager risk attitudes on range improvement decisions. Journal of Range Management 42:242-249.

Bernardo, D. J., D. M. Engle, R. L. Lochmiller, and F. T. McCollum. 1992. Optimum vegetation management under multiple-use objectives in the Cross Timbers. Journal of Range Management 45:462-467.

Boren, J. C., D. M. Engle, M. S. Gregory, R. E. Masters, T. G. Bidwell, and V. A. MAST. 1997a. Landscape structure and change in a hardwood forest-tallgrass prairie ecotone. Journal of Range Management 50:244-249.

Boren, J. C., D. M. Engle, and R. E. Masters. 1997b. Vegetation cover type and avian species changes on landscapes within a wildland-urban interface. Ecological Modeling 103:251-266.

Briggs, J. M., A. K. Knapp, J. M. Blair, J. L. Heisler, G. A. Hoch, M. S. Lett, and J. K. McCarron. 2005. An ecosystem in transition: causes and consequences of the conversion of mesic grassland to shrubland. BioScience 55:243-254.

BRUNER, W. E. 1931. The vegetation of Oklahoma. Ecological Monographs 1:99-188.

Canfield, R. 1941. Applications of the line intercept method in sampling range vegetation. Journal of Forestry 39:388-394.

Dyksterhuis, E. J. 1948. The vegetation of the western cross timbers. Ecological Monographs 18:325-376.

Elwell, H., W. E. McMurphy, and P. W. Santelmann. 1970. Burning and 2,4,5-T on post oak and blackjack oak rangeland in Oklahoma. Stillwater, OK: Oklahoma Agricultural Experiment Station. Bulletin B-675. $11 \mathrm{p}$.

Elwell, H., P. W. Santelmann, J. F. Stritzke, and H. Greer. 1974. Brush control research in Oklahoma. Stillwater, OK: Oklahoma Agricultural Experiment Station. Bulletin B-712. 46 p.

Engle, D. M. 1997. Oak ecology. In: D. Rollins, D. N. Ueckert, and C. G. Brown [EDS.]. Brush Sculptors Symposium Proceedings. San Angelo, TX: TAMU Research \& Extension Center. p 48-60.

Engle, D. M., T. G. Bidwell, and R. E. Masters. 1996a. Restoring cross timbers ecosystems with fire. In: Transactions of the 61st North American Wildlife and Natural Resources Conference. p 190-199.

Engle, D. M., T. G. Bidwell, and M. E. Moseley. 1996b. Invasion of Oklahoma rangelands and forests by eastern redcedar and ashe juniper. Stillwater, OK: Cooperative Extension Service, Oklahoma State University. Circular E-947. $10 \mathrm{p}$.

Engle, D. M., T. L. Criner, J. C. Boren, R. E. Masters, and M. S. Gregory. 1999. Response of breeding birds in the Great Plains to low density urban sprawl. Great Plains Research 9:55-73.

Engle, D. M., And J. F. Stritzke. 1992. Enhancing control of eastern redcedar through individual plant ignition following prescribed burning. Journal of Range Management 45:493-495.

Engle, D. M., And J. F. StRitzke. 1995. Fire behavior and fire effects on eastern redcedar in hardwood leaf litter fires. International Journal of Wildland Fire 5:135-141.
Engle, D. M., J. F. Stritzke, and F. T. McCollum. 1991. Vegetation management in the Cross Timbers: response of understory vegetation to herbicides and burning. Weed Technology 5:406-410.

Ewing, A. L., J. F. Stritzke, and J. D. Kulbeth. 1984. Vegetation of the Cross Timbers Experimental Range, Payne County, Oklahoma. Stillwater, OK: Oklahoma Agricultural Experiment Station Research Report P-856. 40 p.

FLINN, K. M., AND M. VeLLEND. 2005. Recovery of forest plant communities in postagricultural landscapes. Frontiers in Ecology and the Environment 5:243-250.

GREGG, J. 1844. Commerce of the prairies. Reprinted 1933. Dallas, TX: Southwest Press. $438 \mathrm{p}$.

Hallgren, E., M. W. Palmer, and P. Milberg. 1999. Data diving with crossvalidation: an investigation of broad-scale gradients in Swedish weed communities. Journal of Ecology 87:1037-1051.

Hengst, G. E., and J. O. Dawson. 1994. Bark properties and fire resistance of selected tree species from the central hardwood region of North America. Canadian Journal of Forest Research 24:688-696.

Henley, J., R. D. Gelnar, and R. E. Mayhugh. 1987. Soil survey of Payne County, Oklahoma. Washington, DC: USDA, Soil Conservation Service. $268 \mathrm{p}$.

HILL, M. O., AND H. G. GAUCH, JR. 1980. Detrended Correspondence Analysis: an improved ordination technique. Vegetatio 42:47-58.

Hoagland, B. W., I. H. Butler, and F. L. Johnson. 1999. In: R. C. Anderson, J. Fralish, and J. Baskin [EDS.]. The savanna, barren, and rock outcrop communities of North America. New York, NY: Cambridge University Press. p 231-245.

IRVING, W. 1835. A tour on the prairies. Reprinted 1926. Oklahoma City, OK: Harlow Publishing. $252 \mathrm{p}$.

Kreuter, U. P., M. R. Tays, and J. R. Conner. 2004. Landowner willingness to participate in a Texas brush reduction program. Journal of Range Management 57:230-237.

LAY, D. W. 1956. Effect of burning on forage and mast production in southern forests. Journal of Forestry 54:582-584.

Leslie, D. M., JR., R. B. Soper, R. L. Lochmiller, and D. M. Engle. 1996. Habitat use by white-tailed deer on cross timbers rangeland following brush management. Journal of Range Management 49:401-406.

Littell, R. C., G. A. Milliken, W. W. Stroup, and R. D. Wolfinger. 1996. SAS system for mixed models. Cary, NC: SAS Institute, Inc. $633 \mathrm{p}$.

MyeRS, H. R. 1982. Climatological data of Stillwater, Oklahoma, 1893-1980. Stillwater, OK: Oklahoma Agricultural Experiment Station. Research Report P-821. 36 p.

National Oceanic and Atmospheric Administration (NOAA). 1999. Climatological data annual summary, Oklahoma. Volume 107, number 13.

OLIVER, C. D. 1981. Forest development in North America following major disturbances. Forest Ecology and Management 3:153-168.

Palmer, M. W. 1993. Putting things in even better order: the advantages of canonical correspondence analysis. Ecology 74:2215-2230.

Petranka, J. W., and J. K. McPherson. 1979. The role of Rhus copallina in the dynamics of the forest-prairie ecosystem in north-central Oklahoma. Ecology 60:956-965.

PetTit, R. D. 1979. Effects of picloram and tebuthiuron pellets on sand shinnery oak communities. Journal of Range Management 32:196-200.

Quinn, G. P., AND M. J. KEOUGh. 2002. Experimental design and data analysis for biologists. Cambridge, UK: Cambridge University Press. 537 p.

Rasmussen, G. A., AND H. A. Wright. 1988. Germination requirements of flameleaf sumac. Journal of Range Management 41:48-52.

Scifres, C. J., W. T. Hamilton, J. R. Conner, J. M. Inglis, G. A. Rasmussen, R. P. Smith, J. W. Stuth, and T. G. Welch. 1985. Development and implementation of integrated brush management systems (IBMS) for south Texas. College Station, TX: Texas Agricultural Experiment Station Bulletin 1493. 71 p.

Scifres, C. J., J. W. Stuth, And R. W. Bovey. 1981. Control of oaks (Quercus spp.) and associated woody species on rangeland with tebuthiuron. Weed Science 29:270-275.

Smith, A. E., J. J. Silvoy, and L. L. Goodroad. 1987. A soil-conserving system for converting woodland to pasture. Journal of Soil and Water Conservation May-June:198-200.

Sparks, J. C., R. E. Masters, D. M. Engle, M. E. Payton, and G. A. Bukenhofer. 1999. Influence of fire season and fire behavior on woody plants in red-cockaded woodpecker clusters. Wildlife Society Bulletin 27:124-133. 
Stritzke, J. F., D. M. Engle, and F. T. McCollum. 1991. Vegetation management in the Cross Timbers: response of woody species to herbicides and burning. Weed Technology 5:400-405.

Stritzke, J. F., W. E. McMurphy, and R. W. Hammond. 1975. Brush control with herbicides. Stillwater, OK: Oklahoma Agricultural Experiment Station. Miscellaneous Publication MP-95. $36 \mathrm{p}$.

TeR BRAaK, C. J. F. 1986. Canonical correspondence analysis: a new eigenvector technique for multivariate direct gradient analysis. Ecology 67:1167-1179.

TeR BRAAK, C. J. F. 1988. Partial canonical correspondence analysis. In: H. H. Bock [ED.]. Classification and related methods of data analysis. Amsterdam, The Netherlands: North-Holland. p 551-558.
Ter Braak, C. J. F., and P. Šmilauer. 1998. CANOCO reference manual and user's guide to Canoco for Windows: software for canonical community ordination (version 4). Ithaca, NY: Microcomputer Power. $351 \mathrm{p}$.

Therrell, M. D., and D. W. Stahle. 1998. A predictive model to locate ancient forests in the Cross Timbers of Osage County, Oklahoma. Journal of Biogeography 25:847-854.

Weir, J. R., And D. M. Engle. 1999. Brush management for deer hunter habitat. Rangelands 21:36-38.

Wethington, M. K. 1994. A spatial and temporal analysis of forest and grassland change at the Tallgrass Prairie Preserve [M.S. thesis]. Stillwater, OK: Oklahoma State University. 72 p. 